\title{
The Confrontation of COVID-19 in the Brazilian Context in the Light of the Theory of Cognitive Dissonance
}

\section{Júlia Sursis Nobre Ferro Bucher-Maluschke1 ${ }^{*}$, Jonas Carvalho e Silva², Christoph de Oliveira Käppler ${ }^{3}$, José Augusto Evangelho Hernandez ${ }^{4}$}

\author{
${ }^{1}$ Brasília University, Brasília, Brazil \\ ${ }^{2}$ German Chancellor Fellow (Alexander von Humboldt Foundation)/TU Dortmund University, Dortmund, Brazil \\ ${ }^{3}$ Department of Social and Emotional Development in Rehabilitation and Education, Faculty of Rehabilitation Sciences, \\ TU Dortmund University, Dortmund, Brazil \\ ${ }^{4}$ Department of Foundations in Psychology, Institute of Psychology, Rio de Janeiro State University, Rio de Janeiro, Brazil \\ Email: *psibucher@gmail.com
}

How to cite this paper: Bucher-Maluschke, J. S. N. F., e Silva, J. C., de Oliveira Käppler, C., \& Hernandez, J. A. E. (2020). The Confrontation of COVID-19 in the Brazilian Context in the Light of the Theory of Cognitive Dissonance. Psychology, 11, 1691-1704. https://doi.org/10.4236/psych.2020.1111107

Received: July 7, 2020

Accepted: November 15, 2020

Published: November 18, 2020

Copyright (c) 2020 by author(s) and Scientific Research Publishing Inc. This work is licensed under the Creative Commons Attribution International License (CC BY 4.0).

http://creativecommons.org/licenses/by/4.0/

\begin{abstract}
The crisis of the new Coronavirus has provoked existentially threatening reactions in several aspects. This literature review on coping with COVID-19 is based on the theoretical framework of cognitive dissonance theory as applied to the behavior and attitudes of Brazilians. The methodology used was restricted to the following criteria: classical texts of social psychology, such as those of Leon Festinger and his contemporary collaborators, and of the social psychologists of the school of the theory of cognitive dissonance, taking into account its main paradigms. Based on articles published on the difficulties of the Brazilian context in confronting the pandemic, we aim to promote reflections and articulations with the theme. The main concepts of the theory are presented as related to the social dynamics underlying the pandemic, as an explanation, or not, of the adherence processes in the Brazilian context. We suggest that there is dissonance in different groups in Brazil about what is known and what is done, and that many people use simple solutions for complex problems.
\end{abstract}

Keywords

Cognitive Dissonance, Social Dynamics, COVID-19, Brazil

\section{Introduction}

This manuscript aims to reflect the role of cognitive dissonance as a difficulty in 
accepting the visible and even the experienced reality in relation to disease, death, isolation and Brazilian people's living conditions caused by COVID-19. Festinger's (1957) theory has inspired numerous studies, which constitute the state of the art about the influences on attitudes and beliefs, the internalization of values, the ramifications of decisions, the consequences of disagreements and other psychological processes (Harmon-Jones \& Mills, 2019).

There are several challenges for public administration involving the new pandemic, first reported on December 31, 2019 in Wuhan City, China, and which has as parameters the example already experienced in other countries such as Italy, Spain and the United States, with a high numbers of deaths (WHO, 2020). The strategies created to combat the proliferation of the virus are based on the guidelines of the World Health Organization and the countries' own health regulatory bodies. However, as in other countries (Bao, Sun, Meng, Shi, \& Lu, 2020; Bricker, 2020), the COVID-19 outbreak in Brazil has caused social panic and mental health stress at various levels (da Silva, Lordello, Schmidt, \& de Melo Mieto, 2020).

There is a diversity of measures taken by the different countries, which do not always reflect their experienced reality, due to, among other factors, cultural diversity, social organization and the structure of their health systems (Baqui, Bica, Marra, Ercole, \& van der Schaar, 2020). In many cases, strategies such as isolation become relevant in the more favored classes (Ortega \& Orsini, 2020). This measure is not feasible for Brazilian families living in very small and crowded domestic spaces, as in the case of slums and peripheries (da Silva et al., 2020). Another strategy is the constant asepsis of the hands and baths, which does not apply in contexts with difficult access to water. The increase in the consumption of gel alcohol, masks, gloves and protectors for the eyes, led to a decrease in supply in the markets or to price gouging.

Mass confinement tends to aggravate the behaviors already existing before the crisis caused by COVID-19, such as high levels of domestic violence and feminicide in Brazil, the overload of domestic chores performed by women, marital conflicts and recurrent breakups (Mariani, Yukari, \& Amâncio, 2020; da Silva et al., 2020). The problems of overcrowding, poor structure and organization tend to make prisons a free zone for the new coronavirus (SARS-CoV-2) (Portinari \& Mariz, 2020). From the point of view of public administration, dealing with changes in attitudes, beliefs and behaviors is a great challenge. Even creating standards and ordinances to regulate the guidelines of health services, their operationalization becomes very difficult.

The social media have identified a large number of attitudes and behaviors that contradict the conduct recommended by health agencies (Kim, 2020). In addition to the social and economic contingencies applied to most of the population, there are beliefs that are contrary to scientific evidence. This aspect leads us to the theory of cognitive dissonance, through which, in view of reality, there is a difficulty or impossibility to accept the real facts (Festinger, 1957). This oc- 
curs with various types of people, from ordinary citizens to political personalities, who assume leadership roles and function as models to be imitated (Ortega \& Orsini, 2020; Farias \& Pilati, 2020a). This difficulty in accepting the visible and even experienced reality in relation to disease and death leads to different beliefs and actions.

Beginning with the hypothesis that there is dissonance in different groups in Brazil about what people know and what they do, resulting in the repetition of solutions that have been previously demonstrated as being little or not effective. In this sense, dissonance arousal is particularly consequential because it can spur a variety of efforts to reduce discomfort that, in political context, impact democratic funcionting (Vraga, 2015). Moreover, the usual use of simple solutions to complex problems instead of the detailed evaluation of how to promote change was noted.

\section{Method}

This is a narrative review of the scientific literature that describes and discusses the development or "state of the art" of a given subject, from a theoretical or contextual point of view (Bucher-Maluschke, Carvalho e Silva, \& de Souza, 2019). We chose this type of review because in the period in which we outlined the study (March 2020), we found no research reports in the scientific databases on the effects of the pandemic in the Brazilian context. In this case, a more sophisticated review, such as integrative or systematic, would not be appropriate, because the analysis sieves would make it even more difficult to identify the manuscripts in the databases.

To this end, papers, book chapters and few newspaper articles, published in national and international scientific journals, were found in the Scielo, PsycINFO, Scopus, Web of Science and Google Scholar databases, during the period of March to October of 2020, pointing out the predominance or trend of events and concepts applied. Because no studies on the theory of cognitive dissonance related to the confrontation of COVID-19 in Brazil, we selected articles with specific subjects that addressed problems regarding compliance with the norms of distance and social isolation associated with the social context.

\section{Theory of Cognitive Dissonance}

As presented by Festinger (1957), the theory of cognitive dissonance postulates that cognitions (elements of knowledge) may be relevant or irrelevant to each other. When two cognitions are mutually relevant, they can be consonant or dissonant (contradictory) to each other (Sénémeaud \& Somat, 2009; Martinie \& Fointiat, 2010; Kenworthy, Miller, Collins, Read, \& Earleywine, 2011; HarmonJones \& Mills, 2019). A pair of cognitions are consonant if one follows from the other, and they are dissonant if one of them contradicts the other. Dissonance generates psychological discomfort and motivates the person to reduce it, leading to the avoidance of information that may increase it. The greater the magni- 
tude of the dissonance, the greater the pressure to reduce it (Dengah, 2017; McGrath, 2020).

An example adopted by Festinger (1957) may elucidate the theory. A smoker who is aware that smoking is harmful to one's health, is exposed to dissonance due to the knowledge that this awareness contradicts the cognition that they continue to smoke. They can reduce dissonance by changing their behavior, that is, quit smoking, consonant with the cognition that smoking is prejudicial to one's health. Alternatively, smokers can reduce dissonance by changing their cognition about the effects of smoking on their health and about the belief that smoking does not cause negative health effects (eliminating dissonant cognition). They can see the effects of smoking and believe that smoking can reduce tension and prevent weight gain (adding consonant cognitions). Or they may believe that the health risk caused by smoking is not as serious as the risk of automobile accidents and thus reduce the importance of the dissonant cognition). They may also consider the pleasure of smoking as very important to their life (boosting the importance of consonant cognitions).

Festinger used dissonance to refer to the contradiction between cognitions as well as to the resulting psychological discomfort (Rodriguez \& Strange, 2014; AlósFerrer \& Shi, 2012). They are theoretically distinct (Kenworthy et al., 2011). The former currently refers to a cognitive inconsistency or cognitive discrepancy, while the latter refers to a dissonance or dissonant discomfort (Harmon-Jones \& Mills, 2019). These key concepts of psychology can help researchers and public policy promoters identify important gaps in strategies to combat COVID-19 and consider their influences on the economy and public health.

To this end, it is useful to present the common paradigms used in research on cognitive dissonance. Harmon-Jones \& Mills (2019) used a division scheme highlighting the Free-Choice Paradigm, the Belief-Disconfirmation Paradigm, the Effort-Justification Paradigm, and the Induced-Compliance Paradigm, as we present them in the sessions bellow. An important objective generated by research is to understand what happens to individuals after making a decision, the consequences of experiencing information that is inconsistent with previous beliefs, the consequences of the effort required and what happens when people act in ways that are discrepant from their attitudes and beliefs (Harmon-Jones \& Mills, 2019; Kelly, 2019; Van Tongeren, Davis, Hook, Davis, \& Aten, 2019).

\subsection{Free-Choice Paradigm}

The free choice paradigm focuses on the effects of decision making by itself (Kenworthy et al., 2011). After a decision is made, the negative features of the chosen option and the positive features of the rejected option become dissonant with the decision (Alós-Ferrer \& Shi, 2012). On the other hand, each of the positive features of the chosen option and the negative features of the rejected option become consonant with the decision. Difficult decisions should cause more dissonance than easy ones, because there will be more dissonant cognitions after a 
difficult decision than after an easy one. Therefore, a difficult decision will generate greater motivation to reduce the dissonance (Rodrigues \& Strange, 2014).

Studies employing a free-choice paradigm, which ask participants to choose between two alternatives, cause polarization in favor of the chosen option (Vraga, 2015). The dissonance after the decision can be reduced by eliminating negative features from the chosen option or positive feature from the rejected option (Alós-Ferrer \& Shi, 2012). Dissonance can also be reduced by adding positive features to the chosen option or negative features to the rejected option.

Changing the features of decision options to reduce dissonance will lead to the perception of the chosen option as more desirable and the rejected option as less desirable (Harmon-Jones \& Mills, 2019). This effect was called spreading of alternatives, and the experimental paradigm was called the free choice paradigm. In spite of decades of research, as well as recent direct criticism, little investigation has taken place into the processes behind post-decisional attitude change (Keller, 2015).

\subsection{Belief-Disconfirmation Paradigm}

Usually, life is full of experiences when people do or say things that contradict their prior beliefs (Sénémeaud \& Somat, 2009). According to Dissonance increases when people receive information that is incompatible with their beliefs. The challenge increases people's motivation to take action consistent with their beliefs (Cooper \& Feldman, 2020). If the dissonance is not reduced by changing a belief, dissonance can lead to a misperception of the information, to the rejection of the information, to requesting support from those who agree with the belief and to trying to convince others to accept that belief (Dengah, 2017).

In a study of the effect of belief disconfirmation in proselytism, Festinger, Riecken, and Schachter (1956) acted as observers in a group committed to a belief, that was sufficiently specific to be subject to complete disconfirmation. The group believed in a prophecy that a flood would cover the continent. The prophecy was supposedly communicated by aliens from outer space to a woman of the group. The members of the group also believed that they had been chosen to be saved from the flood and evacuated in a flying saucer.

When the flood did not come, the members of the group who were alone abandoned their belief. Members who were with other members kept their faith. The woman who was "receiving transmissions from outer space" reported a new message indicating that the flood had been prevented by God because the group was a force for good. Before the disconfirmation of the belief about the flood, the group became involved in a pattern with little proselytizing. After the disconfirmation, they increased proselytizing substantially. The members of the group attempted to convince others of their beliefs, which would add cognitions compatible with their beliefs.

This belief disconfirmation paradigm, continues to generate insights into dissociation processes (Harmon-Jones \& Mills, 2019). According to Vraga (2015), 
this desire for affirmation is also important in discussion, as people seek social support for their beliefs when experience dissonance. Through its rich and controversial history, from the flood that never happened (Festinger et al., 1956) to the post-diluvian present, dissonance theory has been tested, challenged, reformulated, and reaffirmed (Kenworthy et al., 2011).

\subsection{Effort-Justification Paradigm}

Dissonance is provoked when a person carries out an unpleasant activity to gain some positive result (Harmon-Jones \& Mills, 2019). From the knowledge that the activity is unpleasant comes the decision to cease the activity because the cognition that the activity is unpleasant is dissonant with the involvement in the activity. Similarly, people who expend unpleasant effort to reach a goal psychologically elevate the attractiveness of the goal (Cooper \& Feldman, 2020). The greater the dissonance, the greater the unpleasantness of the effort required to obtain the result.

Dissonance can be reduced by increasing the desirability of the result, which would add consonant cognitions (Harmon-Jones \& Mills, 2019). The difficulty of the choice and the magnitude of the effort are proportional to the degree of eventual linking for, and positive association with, the final outcome (Keller, 2015). Subsequent research in this paradigm showed that more-effortful, or more severely counter-attitudinal or aversive behavior, consequently produced more attitude change than did less-effortful (Kenworthy et al., 2011).

\subsection{Induced-Compliance Paradigm}

The induced Compliance Paradigm is one of the most famous and illustrative paradigm of dissonance, which occurs here when someone says or does something that is contrary to their belief (Fointiat \& Pelt, 2015). From the cognition of that belief, the person might decide not to engage in the behavior, incentives to maintain the behavior and promises of reward or threats of punishment, on the other hand, provide cognitions that justify the behavior.

The higher the frequency and intensity of the cognitions that justify the behavior, the lower the dissonance (Harmon-Jones \& Mills, 2019). Dissonance can be also reduced by changing the belief to correspond more closely to what has been said. Recent research using induced-compliance paradigm has revealed that cognitive dissonance is one mechanism that can underlie situations of memory distortion, in which people often misremember the past as consistent with the present (Rodriguez \& Strange, 2014).

The experiment developed by Festinger \& Carlsmith (1959) to test this paradigm started from the hypothesis that the lower the reward for stating something that is not believed, the greater is the change of opinion necessary to agree with what was said. The results pointed to an aspect defined as counter-attitudinal behavior. The use of this term is derived from the belief that there is a negative relationship between the amount of incentive and the amount of attitudinal 
change required for counter-attitudinal behavior (Fointiat \& Pelt, 2015).

According to Harmon-Jones \& Mills (2019) later research has shown that the negative incentive effect occurs when someone feels free to decide to engage in counter-attitudinal behavior. But when there is no perceived freedom to engage in counter-attitudinal behavior, the opposite effect occurs. In other words, the greater the incentive, the greater the positive attitude (Sénémeaud \& Somat, 2009). When there is no choice as to involvement in the behavior, dissonance is minimized, because there are one or more sufficient justifications for the behavior (McGrath, 2020).

A last variant of this paradigm, which uses threat of punishment in place of promise of reward, is known as the forbidden toy paradigm (Harmon-Jones \& Mills, 2019). In it, the threat of punishment becomes sufficient to dissuade individuals from interacting with an attractive object. Those with mild punishments rate the object less positively than those who suffer severe threats. Examples of other dependent variables within this paradigm include derogating the forbidden toy, not playing with the forbidden toy, or playing with other toys rather than the forbidden one (Kenworthy et al., 2011).

The paradigm of induced compliance and prohibited toys continue to be used to research dissonance processes (Harmon-Jones \& Mills, 2019). Sénémeaud \& Somat (2009) corroborate the fact that the induced-compliance paradigm is a useful heuristic for changing beliefs, opinions, and attitudes in the long term, even when the attitude is particularly stable in the person's cognitive world.

The paradigms above are the most frequently used in tests of the theory of cognitive dissonance (Kenworthy et al., 2011; Harmon-Jones \& Mills, 2019). Other paradigms have been proposed to illustrate a range of possibilities in which dissonance occurs (Fointiat \& Pelt, 2015; Martinie \& Fointiat, 2010; McGrath, 2020). Harmon-Jones \& Mills (2019) point to studies that test how honest or dishonest behavior (betrayal) influences honesty. Dissonance can also occur in other behaviors that are inconsistent with values or moral issues, such as meat consumption, through contemporary discussions of the mass slaughter of animals.

With regard to cultural aspects, research reveals that dissonance processes occur in many cultures, although culture can modulate the causes of dissonance and the ways people reduce it (Kenworthy et al., 2011; Vraga, 2015; Keller, 2015; McGrath, 2020; Dengah, 2017). Dissonance processes are unlikely to be entirely culturally constructed, since dissonance processes have been detected in several animal species, such as pigeons, white rats and capuchin monkeys (Harmon-Jones \& Mills, 2019).

\section{Dissonant Aspects of Brazilian Groups in the Fight against COVID-19}

In Brazil, religion, according to some churches, promotes the idea that the pandemic stems from some divine punishment, or work of the Evil One, the result of a sinful society, among other transcendental attributions, according to the monitor- 
ing carried out by the Laboratory of Anthropology of Religion of UNICAMP (Bandeira \& Mendes, 2020). In this context prevention and healing arise through individual and collective prayers to combat the evil that spreads over the earth. Religion is a primary 'instrument for coping in adversity (Dengah, 2017). However, in these moments, people may encounter dissonance in religious attitudes and experiences. For example, individuals of varied religiosity may differ in the way they perceive the divine and how they experience it. In the United States, Van Tongeren, Davis, Hook, Davis, \& Aten (2019) examined whether the importance of religious belief modulated the effects of threatening stimuli (e.g. natural disasters) on religious cognitive dissonance. The results revealed that exposure to these stimuli increased the discrepancy between the perception of doctrine and relational experience with religion, in relation to God's benevolence among participants with little religiosity. To those for whom religion is central, it seemed more appropriate to integrate threatening situations with their belief systems in ways that did not provoke cognitive dissonance, and thus help them maintain cognitive equilibrium.

At the same time, many Brazilian neo-Pentecostal churches follow the same line about SARS-CoV-2 as evangelical preachers of U.S. television (Milz, 2020). Several temples of large churches remain open, however the media has reported a general decline in regular attendance, because the more the press announces, the more people receive qualified information, realize the risks, and take action to adopt combat behavior, which contradicts what the religious leaders of these denominations say. In addition to the great churches, there is also a universe of small religious groups that influence the attitudes of the faithful, especially in poor communities.

Another aspect resulting from the reality we live is the search for a scapegoat to justify this scourge. China has been a very recurring target in social networks such as the country, and political system, causing the emergence of the virus and even its spread in other countries (Gomes, 2020). The increase in fake news in the international context is frightening to the extent that negative and/or romantic contradictory ideas circulate the internet in the midst of social isolation, further provoking feelings of insecurity (Kim, 2020). Conspiracy theories related to the explanations of the presence of COVID-19 have arisen in abundance, and become beliefs, for those who lose the capacity for reflection and whose cognition it the face of reality becomes unbearable, hence the need for scapegoats.

In order to assess the role of political partisanship, conspiracy beliefs, and intolerance of uncertain, Farias \& Pilati (2020a) examine the criterion of support for COVID-19 prevention measures and the criterion of compliance with social distancing. After applying surveys in 662 participants and using regression analyses to examine the data collect, the results indicated that political partisanship predicts conspiracy theories. Political partisanship predicted support to COVID-19 prevention measures while intolerance of uncertainty predicted past compliance with social distancing. The study suggests the relevance of diminishing political 
polarization around the virus, providing basic scientific knowledge on the general population to make it easier to identify fake data and conspiracy theories, and offering psychological support focused on dealing with uncertainty to assist in increasing endorsement of and compliance with prevention measures.

In another study, Farias \& Pilati (2020b) investigated the role of some variables (political partisanship, income, professional status, gender, age, social norms, and intolerance of uncertainty) in intentions of non-compliance with social distancing measures. After applying an online questionnaire to 2056 Brazilians, findings indicated that individuals that support right-wing parties, are currently unemployed, young and male, and have low job stability, lower wages and a higher intolerance of uncertainty tendency are more prone to have stronger intentions of violating social distancing measures. Social norms also play a significant role in the intentions of violation but only when using ingroup members (family and friends) as referents. The authors discuss the need for support from relevant political figures to social distancing policies. They also indicated that providing psychological support and cash transfer programs may increase compliance with physical distancing. Plus, the results suggested that initiatives to persuade individuals to stay at home would be more effective if they focus on ingroup members.

As a heterogenous and diverse group, da Silva et al. (2020) discussed the impact of COVID-19 on Brazilian families considering socioeconomic data from before and during the outbreak. The data analysis pointed out families in which members may have lost their jobs or are living from informal work face the challenge of protecting themselves from COVID-19. Access to healthcare has proven to be more precarious for the poor, Indigenous, Black, street population, women, and LGBTQI+. Impacts on the mental health of family members who comply with social isolation and are overburdened with domestic duties, home office and their children's education by digital media are increased by stress, anxiety, and uncertainties about the future (da Silva et al., 2020). Due to the great impact of COVID-19 on Brazilian families, existing socioeconomic iniquities increased during the pandemic. Unemployment, poor basic sanitation conditions and a high rate of informal work contrast with the situation of high-income families. The authors (da Silva et al., 2020) concluded that the post-pandemic period will be decisive for Brazil to prioritize the recovery of its already existing public policies. They suggested the proposed initiatives be organized around the goal of mitigating adverse effects on mental health aggravated by COVID- 19 .

The results of these three studies lead us to suppose that, beliefs in isolation to fight the virus, and in non-isolation due to non-belief in the virus, are translated by the responses of people who adhere to social distancing. Despite the danger of contamination and death, the workers' need for survival, especially the informal ones, leads many people to come out of isolation. On the other hand, the government has adopted emergency measures to help the poor financially, in order for isolation to be maintained. In this sense we might suggest that social inequa- 
lity can raise dissonance during the confrontation process of COVID-19 in Brazil. The study below is an example of the social implications on the effects of the pandemic in the Brazilian context.

Aiming to characterize the COVID-19 pandemic in Brazil and assess variations in mortality according to region, ethnicity, comorbidities and symptoms, Baqui et al. (2020) conducted a cross-sectional observational study of hospital morbidity provoked by the virus. They found evidence of two distinct but associated effects: increased mortality in the northern region (regional effect) and in the Pardo and black populations (ethnicity effect). The results speculate that the regional effect is driven by increasing comorbidity burden in regions with lower levels of socioeconomic development. The ethnicity effect was considered to be related to differences in susceptibility to COVID-19 and access to health care (including intensive care) across ethnicities. The author's analysis supports an urgent effort on the part of Brazilian authorities to consider how the national response to COVID-19 can better protect Pardo and Black Brazilians, as well as the population of poorer states, from their higher risk of dying of COVID-19.

Another aspect to be considered is the solidarity behaviors in the face of the difficulties experienced by specific and more vulnerable groups. Many individuals are prevented from leaving their homes, such as the elderly and chronic patients, and at this moment, there is an increase in the need for help to perform routine activities, such as going out to buy food (Alcoforado, 2020). Thus, we observe the initiatives of groups, companies and civil organizations that attend to these needs. These good practices promote greater awareness of the communities about the importance of remaining in isolation, contributing to the reduction of dissonant aspects related to COVID-19.

Due the political crisis within the Brazilian government, Ortega \& Orsini (2020) discuss the term "para-state" in relation to contexts where state presence is limited, in which nevertheless remains present and potent. The authors argue that the current form (or lack) of public health governance can best be described as governance without (central) government. In these "para-state" contexts, the essay reports new forms of solidarity and "mutual aid" for mobilization and survival are emerging, some through pre-existing NGO structures, and others by building relationships and social networks from the ground up. Therefore, we may highlight that solidarity may increase compliance in forms of governance without the State.

The studies reviewed in this essay pointed to the government as one of the main problems faced by Brazilians in dealing with the pandemic. Dissonance may not be a universal response to potentially arousing tasks, but when only some groups experience dissonance and polarization after enumerating the benefits of an opposing party, it may bias democratic functioning (Vraga, 2015).

In this context, the role of leaders, as models of behavior, exerts a very strong influence over a significant portion of society. From the point of view of the population, the measures of economic compensation adopted by public admin- 
istrators are insignificant, in relation to the gain if they could be working, despite the proliferation of the virus. This discrepancy leads to the dissonant idea that the virus does not reach them, which demonstrates the conflict between the measures adopted and the behavior of people under this existentially threatening phenomenon. If these leaders also have difficulty accepting the visible reality of sickness and death, what do they expect from those who follow their ideas as absolute truth?

We argue, as an answer, that the relationships among research, action, policy and practice are better explained as interactions among many actors. This includes researchers, policymakers, health professionals, opinion makers, journalists, politicians, officials, pressure groups, personal interests, industry, commerce and members of the public. Given the reality of the advance of the spread of the virus in the global context, there are several levels of cognitive dissonance in Brazil in the political, social and economic areas within the context of the managers and the population in general.

The interaction among these groups has emerging properties that include policy and practice results. It is from the perspective of this exchange of ideas that cognitive biases, such as dissonance, play a significant role in the formation of discourse (Kelly, 2019). Therefore, emergency economic measures to combat the impacts of the pandemic should be developed to better address the consequences of dissonance in mental health at the macrosocial level.

\section{Final Considerations}

This study aimed to explore theoretically what is occurring in the acceptance or not of measures to combat COVID-19. The theory of cognitive dissonance was proposed as a framework for understanding people's behaviors in this context. Among the dissonant aspects addressed is the influence of religious groups, political leaders and the needs of workers, especially commercial and informal ones. In this way, public assistance and education programs, which are important for the survival of vulnerable groups, are closed. Several variants of the theory of cognitive dissonance affirm, as does the original version, that situations that generate dissonance generate motivation for genuine cognitive change. However, the dissonant aspects in the Brazilian groups support the theoretical interpretations that may be different from the phenomena observed in the experiments on cognitive dissonance.

Certainly, the narrative review brings several limitations to the study, as it is more indicated for the production of dissertations and theses. The absence of a protocol, for filtering the selection of articles in the databases and assessing the quality of the selected studies, is an impediment for a conventional review. However, it is worth pointing out that theory should underpin any scientific undertaking for which an evaluation or operational tool is to be developed. Thus, the pandemic phenomenon and its effects still demand great theoretical and empirical efforts from the scientific community. This review may also provide sub- 
sidies to researchers interested in the theory of cognitive dissonance.

\section{Conflicts of Interest}

The authors declare no conflicts of interest regarding the publication of this paper.

\section{References}

Alcoforado, R. (2020). Em tempos de pandemia, ações de voluntários dão exemplo de solidariedade no Recife (pp. 1-17).

https:/g1.globo.com/pe/pernambuco/noticia/2020/04/01/em-tempos-de-pandemia-ac oes-de-voluntarios-dao-exemplo-de-solidariedade-no-recife.ghtml

Alós-Ferrer, C., \& Shi, F. (2012). Choice-Induced Preference Change: In Defense of the Free-Choice Paradigm. SSRN Electronic Journal, 10, 34-49.

https://doi.org/10.2139/ssrn.2062507

Bandeira, O., \& Mendes, G. (2020). Religious Programs Advocate Open Temples and Faith against Coronavirus (pp. 1-9). CartaCapital.

https://www.cartacapital.com.br/blogs/intervozes/programas-religiosos-defendem-tem plos-abertos-e-fe-contra-coronavirus/

Bao, Y., Sun, Y., Meng, S., Shi, J., \& Lu, L. (2020). 2019-nCoV Epidemic: Address Mental Health Care to Empower Society. The Lancet, 395, e37-e38. https://doi.org/10.1016/S0140-6736(20)30309-3

Baqui, P., Bica, I., Marra, V., Ercole, A., \& van der Schaar, M. (2020). Ethnic and Regional Variations in Hospital Mortality from COVID-19 in Brazil: A Cross-Sectional Observational Study. The Lancet Global Health, 8, e1018-e1026.

https://doi.org/10.1016/S2214-109X(20)30285-0

Bricker, D. (2020). Public Divided on Whether Isolation, Travel Bans Prevent COVID-19 Spread; Border Closures Become More Acceptable.

https://www.ipsos.com/sites/default/files/ct/news/documents/2020-03/coronavirus-wa ve-5-pr-ipsos_0.pdf

Bucher-Maluschke, J. S. N. F., Carvalho e Silva, J., \& de Souza, I. B. dos S. (2019). Revisão sobre o presídio feminino nos estudos brasileiros. Psicologia \& Sociedade, 31, e216159. https://doi.org/10.1590/1807-0310/2019v31216159

Cooper, J., \& Feldman, L. A. (2020). Helping the "Couch Potato": A Cognitive Dissonance Approach to Increasing Exercise in the Elderly. Journal of Applied Social Psychology, 50, 33-40. https://doi.org/10.1111/jasp.12639

da Silva, I. M., Lordello, S. R., Schmidt, B., \& de Melo Mietto, G. S. (2020). Brazilian Families Facing the COVID-19 Outbreak. Journal of Comparative Family Studies, 51, 324336. https://doi.org/10.3138/jcfs.51.3-4.008

Dengah, H. J. F. (2017). Being Part of the Nação: Examining Costly Religious Rituals in a Brazilian Neo-Pentecostal Church. Ethos, 45, 48-74. https://doi.org/10.1111/etho.12154

Farias, J., \& Pilati, R. (2020a). COVID-19 as an Undesirable Political Issue: Conspiracy Beliefs and Political Partisanship Predict Adhesion to Sanitary Measures. https://doi.org/10.31234/osf.io/97gn4

Farias, J., \& Pilati, R. (2020b). Violating Social Distancing amid the COVID-19 Pandemic: Psychological Factors to Improve Compliance. https://doi.org/10.31234/osf.io/apg9e

Festinger, L. (1957). A Theory of Cognitive Dissonance. Stanford, CA: Row, Peterson and Company. 
Festinger, L., \& Carlsmith, J. M. (1959). Cognitive Consequences of Forced Compliance. The Journal of Abnormal and Social Psychology, 58, 203-210. https://doi.org/10.1037/h0041593

Festinger, L., Riecken, H. W., \& Schachter, S. (1956). When Prophecy Fails. Minneapolis, MN: University of Minnesota Press. https://doi.org/10.1037/10030-000

Fointiat, V., \& Pelt, A. (2015). Do I Know What I'm Doing? Cognitive Dissonance and Action Identification Theory. The Spanish Journal of Psychology, 18, E97. https://doi.org/10.1017/sjp.2015.93

Gomes, M. E. (2020). Virus, Ignorance and Prejudice (pp. 1-9). https://veja.abril.com.br/blog/marcos-emilio-gomes/virus-ignorancia-e-preconceito/

Harmon-Jones, E., \& Mills, J. (2019). An Introduction to Cognitive Dissonance Theory and an Overview of Current Perspectives on the Theory. In E. Harmon-Jones (Ed.), Cognitive Dissonance: Reexamining a Pivotal Theory in Psychology (2nd ed., pp. 3-24). Washington DC: American Psychological Association. https://doi.org/10.1037/0000135-001

Keller, K. T. (2015). Explorations in the Psychology of Choice: Does Choice Arouse Cognitive Dissonance? Princeton, NJ: Princeton University. http://gateway-proquest.ez54.periodicos.capes.gov.br/openurl?url_ver=Z39.88-2004\&rf t_val_fmt=info:ofi/fmt:kev:mtx:dissertation\&res_dat=xri:pqm\&rft_dat=xri:pqdiss:3711 663

Kelly, M. P. (2019). Cognitive Biases in Public Health and How Economics and Sociology Can Help Overcome Them. Public Health, 169, 163-172. https://doi.org/10.1016/j.puhe.2019.02.012

Kenworthy, J. B., Miller, N., Collins, B. E., Read, S. J., \& Earleywine, M. (2011). A TransParadigm Theoretical Synthesis of Cognitive Dissonance Theory: Illuminating the Nature of Discomfort. European Review of Social Psychology, 22, 36-113. https://doi.org/10.1080/10463283.2011.580155

Kim, B. (2020). Effects of Social Grooming on Incivility in COVID-19. Cyberpsychology, Behavior, and Social Networking, 23, 519-525. https://doi.org/10.1089/cyber.2020.0201

Mariani, D., Yukari, D., \& Amâncio, T. (2020). Murders of Women at Home Double in SP during Coronavirus Quarantine (pp. 11-14). Folha de São Paulo.

https://www1.folha.uol.com.br/cotidiano/2020/04/assassinatos-de-mulheres-em-casa-d obram-em-sp-durante-quarentena-por-coronavirus.shtml

Martinie, M.-A., \& Fointiat, V. (2010). Enfreindre sans craindre: Tolérance à la dissonance dans le paradigme de l'hypocrisie induite. Psychologie Française, 55, 41-47. https://doi.org/10.1016/j.psfr.2010.02.003

McGrath, A. (2020). Bringing Cognitive Dissonance Theory into the Scholarship of Teaching and Learning: Topics and Questions in Need of Investigation. Scholarship of Teaching and Learning in Psychology, 6, 84-90. https://doi.org/10.1037/stl0000168

Milz, T. (2020). Evangelicals Choir with Bolsonaro and Deny Risks of Coronavirus (pp. 1-4). Deutsche Welle.

https://www.dw.com/pt-br/evangélicos-fazem-coro-com-bolsonaro-e-negam-riscos-do -coronavírus/a-53000050

Ortega, F., \& Orsini, M. (2020). Governing COVID-19 without Government in Brazil: Ignorance, Neoliberal Authoritarianism, and the Collapse of Public Health Leadership. Global Public Health, 15, 1257-1277. https://doi.org/10.1080/17441692.2020.1795223

Portinari, N., \& Mariz, R. (2020). Coronavirus: Moro Acknowledges Worsening of Contagion in Prisons, but Says It Is "Under Control"(pp. 1-5). The Globe.

https://oglobo.globo.com/brasil/coronavirus-moro-reconhece-piora-do-contagio-em-p residios-mas-diz-que-esta-sob-controle-1-24368885 
Rodriguez, D. N., \& Strange, D. (2014). Dissonance-Induced False Memories: Evidence from a Free-Choice Paradigm. Journal of Cognitive Psychology, 26, 571-579. https://doi.org/10.1080/20445911.2014.925459

Sénémeaud, C., \& Somat, A. (2009). Dissonance Arousal and Persistence in Attitude Change. Swiss Journal of Psychology, 68, 25-31. https://doi.org/10.1024/1421-0185.68.1.25

Van Tongeren, D. R., Davis, E. B., Hook, J. N., Davis, D. E., \& Aten, J. D. (2019). Existentially Threatening Stimuli Increase Religious Cognitive Dissonance among the Less Intrinsically Religious. Psychology of Religion and Spirituality. https://doi.org/10.1037/rel0000296

Vraga, E. K. (2015). How Party Affiliation Conditions the Experience of Dissonance and Explains Polarization and Selective Exposure. Social Science Quarterly, 96, 487-502. https://doi.org/10.1111/ssqu.12138

WHO (2020). Coronavirus Disease 2019 (COVID-19) Situation Report-87. https://www.who.int/docs/default-source/coronaviruse/situation-reports/20200416-sitr ep-87-covid-19.pdf?sfvrsn=9523115a_2 